\title{
ET QUASI PROPRIUM ET SANCTISSIMUM TEMPLUM IUSTITIAE CONSECRARE
}

\begin{abstract}
A hatodik század talán legnagyobb műgonddal elkészített törvénymüve Iustinianus császár nevéhez füződik. A császár a klasszikus római tradíció helyreállítójaként és a megújult keresztény birodalom első uralkodójaként tekintett magára, és ennek föként rendeleteiben adott hangot. Törvénykönyveinek bevezető rendeleteiben kettős birodalmi célkitűzését, nevezetesen az imperium Romanum visszahódítását és a klasszikus jogtudomány kodifikálását mint Istennek tett szolgálatot jeleníti meg. Iustinianus keresztény kodifikációjának középpontjában a Digesta áll, amelynek a császár különleges szerepet szentelvén, mintegy az igazságosság saját legszentebb templomaként emelte alattvalói fölé.
\end{abstract}

Kulcsszavak: Iustinianus, kodifikáció, Digesta, Deo auctore, Tanta, $\Delta \varepsilon ́ \delta \omega \kappa \varepsilon v$

Iustinianus császár Kr. u. 527-565-ig uralkodott a Római Birodalom felett, ${ }^{1}$ és neve elválasztathatatlanul összefonódott a római joggal, tekintettel arra, hogy a római jog forrásainak nagy részét a nevéhez füződő monumentális kodifikáció szerencsére teljes egészében fennmaradt müveiből (Institutiones, Digesta seu Pandectae és Codex Iustinianus) ismerjük. Ahogy Peter Stein, cambridge-i római jogász professzor fogalmaz: „kodifikációja része volt ama becsvágyó tervnek, amely a Római Birodalom tündöklését volt hivatott feléleszteni valamennyi területen.”2 Iustinianus tudatosan a klasszikus jogtudomány korszakát törekedett helyreállítani egy második aranykorként. A iustinianusi jog az Augustus uralkodásával megkezdődő ún. klasszikus jogtudomány korának színvonalára igyekezett a római jogot visszajuttatni, minél inkább megtisztítva

\footnotetext{
${ }^{1}$ Iustinianus, eredeti nevén Flavius Petrus Sabbatius Iustinianus, Iustinus császár unokaöccse volt, akit nagybátyja adoptio útján tett örökösévé. Iustinianus családja a ma elfogadott többségi nézet szerint trákillír eredetű volt, és bár szülőhelye a túlnyomórészt görög nyelvű birodalomfél területéhez tartozott, mégis Iustinianus valószínüleg latin anyanyelvü volt. Lásd Földi A. - Hamza G.: A római jog története és institúciói. Budapest 2016 21. 94. Vö. továbbá J. Shepard (ed.): The Cambridge History of the Byzantine Empire 500-1492. Cambridge 2008. 105; B. Stolte: Justice: Legal Literature. In: E. Jeffreys - J. H. R. Cormack (eds.): The Oxford Handbook of Byzantine Studies. Oxford 2008. 691-692; M. Maas: Roman Questions, Byzantine Answers: Contours of the Age of Justinian. In: M. Maas (ed.): The Cambridge Companion to the Age of Justinian. Cambridge 2005. 5 skk.

2 P. Stein: A római jog Európa történetében. Budapest 2005. 49.
} 
azt a posztklasszikus jogfejlődés és - különösen - a vulgárjog hatásaitól. ${ }^{3}$ Az aranykor visszaállítása mint birodalmi program megmutatkozott a hódításokban, az építkezésekben (például Hagia Sophia székesegyház) és a jogalkotásban egyaránt, és miként az augustusi korban Horatius carmen saecularejában elevenedett meg az akkori korszellem, éppúgy ennek visszatérését láthatjuk a iustinianusi hatályba léptető rendeletek magas szépirodalmi színvonalú szövegeiben is.

Az új aranykor tudatos megélését legmarkánsabban egy Ilias-allúzió tükrözi, amelyet a jogi oktatás tantervét tartalmazó Omnem kezdetű constitutio szövege tartalmaz:

Incipite igitur legum doctrinam eis dei gubernatione tradere et viam aperire quam nos invenimus, quatenus fiant optimi iustitiae et rei publicae ministri et vos maximum decus in omne saeculum sequatur: quis vestris temporibus talis legum inventa est permutatio, qualem et apud Homerum patrem omnis virtutis Glaucus et Diomedes inter se faciunt dissimilia permutantes:

$\chi \rho \dot{v} \sigma \varepsilon \alpha \chi \alpha \lambda \kappa \varepsilon i \omega v, \dot{\varepsilon} \kappa \alpha \tau o ́ \mu \beta o \imath \alpha$

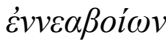

(id est: aurea aheneis, centum boum pretio aestimata cum aestimatis bubus novem).

quae omnia optinere sancimus in omne aevum, ab omnibus tam professoribus quam legum auditoribus et librariis et ipsis et iudicibus observanda.

(Omnem 11)
Kezdjétek tehát el a törvények ismeretét Isten vezetésével átadni és utat nyitni nekik, amelyet mi megtaláltunk, hogy azáltal az igazságosság és államunk legkiválóbb szolgálóivá váljanak, és titeket a legfőbb dicsőség kövessen minden időben: a ti időtökben a törvényeknek valamiféle olyan cseréje ment végbe, amilyent Homérosznál, valamennyi erény atyjánál, Glaucus és Diomedes tesznek egymás között különböző értékű tárgyakat kicserélve:

„Aranyat a bronzra, száz marhával felérőt kilenccel felérőkre"

(azaz aranyat bronzzal, száz marhaértékűt kilenc marha árával)

És mindezeket szentesítjük, hogy minden korban érvényesek legyenek, és éppúgy minden jogtanár, mint a jogtanulók, könyvmásolók és maguk a bírák is vegyék figyelembe.

Glaukos és Diomédés története Homéros Iliasának egy közismert epizódja (Hom. Il. 6, 119-236), amelyben a két - egymással a harcmezőn ellenségként találkozó - ellenfél felismeri, hogy atyáik révén tulajdonképpen vendégbarátság füzi őket egymáshoz. Ez pedig olyannyira erős kötelék, hogy nem támadnak egymásra, ehelyett kicserélik páncélzatukat. Az epizód zárósorai a következőképp hangzanak:

3 Stein: i. m. (2. jegyz.) 49 hozzáteszi, hogy emellett célja volt egy olyan joganyag megalkotása is, amely korának igényeihez a legmegfelelőbb lett volna, ám a két cél nem bizonyult összeegyeztethetőnek. Ehhez még részletesen lásd L. Wenger: Die Quellen des römischen Rechts. Wien 1953. 562-563; Földi - Hamza: i. m. (1. jegyz.) 94; Shepard: i. m. (1. jegyz.) 108. 


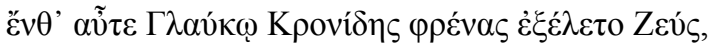

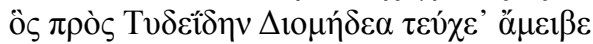
$\chi \rho \cup ́ \sigma \varepsilon \alpha \chi \alpha \lambda \kappa \varepsilon i ́ \omega v, \dot{\varepsilon} \kappa \alpha \tau o ́ \mu \beta o \imath ' \dot{\varepsilon} v v \varepsilon \alpha \beta o i ́ \omega v$.

(Hom. Il. 6, 234-236) ${ }^{4}$

Felmerülhet a kérdés, hogy miért zárul az Omnem ezen betéttel, vajon mi lehet az allúzió funkciója a szövegben, amelyről Wenger megállapítja, hogy igen távoli (s ekként némiképp erőltetett) hivatkozás, és nem utolsó sorban Iustinianus saját munkájának feldicsérése. ${ }^{5}$

Az idézett Ilias-sor értelme szimbolikus: előtte a szövegben az szerepel, hogy quis vestris temporibus talis legum inventa est permutatio, azaz arról a változásról van szó, amelyet magával hozott a kodifikáció. Kérdés természetesen, hogy mi cserélt helyet mivel. Az a kaotikus anyag, amelyből a kompilátorok dolgoztak, nevezetesen a régi jog mérhetetlen kötetei, az ismétlődő és sokszor felesleges szabályok cseréltek-e helyet a kodifikáció harmonikus és rendezett művével, vagy elképzelhető egy másik olvasata is a szövegnek? Ez a mindenkori olvasó interpretációján múlik. Ugyanis a szöveget úgy is olvashatjuk, hogy a régi jog (ius vetus) mérhetetlen irodalma az arany, amelyet egy méreteiben kisebb corpusra cserélnek el, nevezetesen a kodifikáció nyomán megszületett törvénymüvekre, azaz a bronzra. Minthogy az arany kis mennyiségben is többet ér, mint a nagy mennyiségű bronz, ez olyan erős (ön)iróniát jelentene, amely aligha lenne illő a tanrendről szóló rendelet zárásaként.

Tehát sokkal inkább fordítva kell értenünk, azaz a kaotikus anyag, amelyből a kompilátorok kiindultak, felel meg a bronznak, a törvénymüvek pedig az aranynak. A rendelet nem véletlenül hangsúlyozza ezt, Iustinianus saját korát mint egy bronzkor után beköszöntő új aranykort szerette volna lefesteni, ${ }^{6}$ amely az imperium Romanum visszahódítását és a régi jog restaurációját célozta meg. Eme programjának hirdetéséhez pedig legkézenfekvőbb eszköznek éppen törvénymüveinek prooimionjai kínálkoztak, amelyeket arra használt fel, hogy a császári propagandát minél szélesebb körben terjeszthesse.

Míg manapság a hatályba léptető törvények száraz jogi szövegei a legkevésbé sem nyújtanak intellektuális élményt olvasójuknak, Iustinianus vonatkozó rendeletei tudatosan felépített, egyértelmüen irodalmi igényü alkotások, amelyek a kódexek törvényerővel való felruházásán túl egy további célt is szolgáltak, nevezetesen a birodalmi propagandát. ${ }^{7}$ A rendeletek irodalmi stílusa magasabb nyelvi regiszter alkalmazásával emeli a

4 „Ekkor azonban Glaukosz eszét Kronidész elorozta, / mert ez aranyfegyvert nyujtott át Tűdeidésznek / rézért, százökör-étékűt a kilencökör-árért.” Devecseri Gábor fordítása.

5 Wenger: i. m. (3. jegyz.) 637.

${ }^{6}$ A második aranykor gondolata pedig egy, a római költészetben jelen lévő toposz, amely újra és újra felbukkan, így Horatiusnál vagy Vergiliusnál. Iustinianus 'grand design'-ja ezt a második aranykort volt hivatott újra elhozni.

7 Maas: i. m. (1. jegyz.) 6 sk; Földi-Hamza: i. m. (1. jegyz.) 94. 
szövegeket az irodalmi alkotások szintjére, különösen azáltal, hogy a jogi szaknyelvezet mellé metaforák, hasonlatok, továbbá más költői és retorikai eszközök kerülnek.

Iustinianusnak mind kodifikációs tevékenységére, mind egész életművére vonatkozóan a szakirodalomban viszonylag egységes képet találunk.

Franz Wieacker Iustinianus tervét, tehát az egykori imperium Romanum helyrállításának programját (Justinians Restaurationsprogramm), egy katonai, vallási és jogi egységre való folyamatos törekvésként jellemzi. ${ }^{8}$

Peter Sarris szerint Iustinianus törekvései az egységes vallás megszilárdítására irányultak, amelynek keretében az uralkodó személyének helye és feladatai is megváltoztak a korábbiakhoz képest. ${ }^{9}$ Iustinianus vallási intézkedései kéz a kézben jártak jogi reformjaival, nevezetesen az 528-tól 534-ig tartó kodifikációval. ${ }^{10}$ Iustinianus valamenynyi törekvése azt a közös célt szolgálta, hogy a római császár tekintélye és hatalma újra teljessé váljon az egész Római Birodalom felett. ${ }^{11}$

Michael Maas megközelítése ezt a képet annyiban árnyalja, hogy Iustinianust átmenetként tekintve a római múlt és a bizánci-középkori jövő között, kétarcú uralkodóként ábrázolja. Keresztény uralkodó létére Iustinianus rendeleteiben a rómaiság kontinuitását hangsúlyozta, és ennek talán legmeggyőzőbb bizonyítéka, hogy reformjait is képest volt a restauráció köntösébe bújtatni. ${ }^{12}$

Jonathan Shepard Iustinianus említett tervét 'grand design'-nak nevezi, ${ }^{13}$ amelynek része volt a kodifikáció mellett az imperium Romanum elveszett területeinek, így az észak-afrikai, hispániai és itáliai területeknek a visszahódítása, ${ }^{14}$ továbbá a várostervezés, így olyan középületek építése Konstantinápolyban, mint a Hagia Sophia, ${ }^{15}$ végső soron egy keresztény Római Birodalom létrehozása. ${ }^{16}$ Ahogy Shepard fogalmaz: „The

${ }^{8}$ F. Wieacker: Römische Rechtsgeschichte. Bd. 2. München 2006. 287.

9 P. Sarris: Economy and Society in the Ages of Justinian. Cambridge 2006. 206.

10 Sarris: i. m. (9. jegyz.) 208.

11 Sarris: i. m. (9. jegyz.) 216.

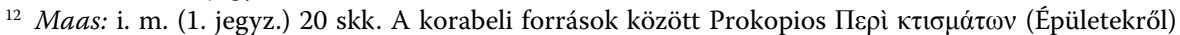
című műve is egy ilyen Iustinianus képét festi le, míg köztudott, hogy egy másik nevezetes művében, az

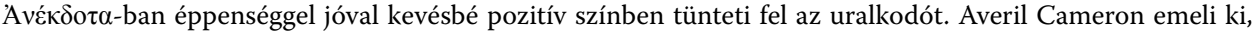
hogy Iustinianus alakja Prokopiosnál hol démonikus, hol egyenesen szent, ami talán Iustinianus uralkodásának megítélésében mutatkozó társadalmi ellentéteket is képviselheti, ugyanakkor tény, hogy Prokopios őszinte véleményéről semmit sem tudunk. Lásd részletesen A. Cameron: Procopius and the Sixth Century. Berkeley - Los Angeles. 1985. 86-88. Szintén a restaurációs programhoz lásd még D. Karamboula: Von Diocletian zu Iustinian. Kontinuität und Legitimität in der Beziehung zwischen Kaisern und Untertanen. Berlin 2015. 15-16.

13 Shepard: i. m. (1. jegyz.) 107.

${ }^{14}$ L. Bréhier: Bizánc tündöklése és hanyatlása. Budapest $1999^{2} .31$ skk.

15 Shepard: i. m. (1. jegyz.) 106. Az épületekhez részletes antik forrásunk Prokopios már idézett Пepì $\kappa \tau 1 \sigma \mu \alpha ́ \tau \omega \nu$ címủ mủve a Iustinianus által építtetett templomok, a palota és egyéb középületek leírását tartalmazza. Lásd még ehhez Maas: i. m. (1. jegyz.) 21 skk.

${ }^{16}$ Lásd Shepard: i. m. (1. jegyz.) 107; A. M. Honoré: The Background to Justinian's Codification. Tulane Law Review 48 (1973/1974) 859-893. Iustinianus egyház-egységesítő törekvéseihez lásd részletesen Sáry P.: Iustinianus egységtörekvései egyházügyi téren. Iustum Aequum Salutare VI (2010/4). 205-216. 
temptation to see all these as parts of a jigsaw which, when correctly fitted together, yield some grand design is hard to resist."17

A kodifikációt két előkészítő és öt életbe léptető rendelet kíséri, valamint az Omnem kezdetű constitutio, amely a jogi oktatás tantervét tartalmazza. Ezek időben a következőképp követik egymást:

Haec quae necessario [528. febr. 13]

Summa [529. ápr. 7.]

Deo auctore [530. dec. 15.]

Omnem [533. dec. 16.]

Imperatoriam [533. nov. 21.]

Tanta [533. dec. 16.]

$\Delta \dot{\varepsilon} \delta \omega \kappa \varepsilon v$ [533. dec. 16.]

Cordi nobis [534. dec. 29.]
$>$ Codex Iustinianus

$>$ Codex Iustinianus

$>$ Digesta seu Pandectae

$>$ Digesta seu Pandectae

$>$ Institutiones seu Elementa

$>$ Digesta seu Pandectae

$>$ Digesta seu Pandectae

$>$ Codex Iustinianus repetitae praelectionis

A bevezető rendeleteket kifinomult, emelkedett stílus jellemzi, ami igen gyakran sokszorosan összetett (átlagosan 9-10 soros) mondatokkal nehezíti meg az olvasó feladatát. A díszítettség, különösen a Digestát és az Institutionest előkészítő és életbe léptető rendeleteket jellemzi, így a Deo auctore, az Omnem, a Tanta/ $\Delta \dot{\delta} \delta \omega \kappa \varepsilon v$ és az Imperatoriam jellegzetessége. A két császári rendeletgyűjteményhez tartozó bevezető rendeletek, így a Haec quae necessario, a Summa és a Cordi nobis inkább csak bevezetőjükben tartalmaznak díszítettebb mondatokat, majd ezt követően tényleges funkciójukat töltik be, és a jogi szövegekre jellemző, jobbára száraz stílust veszik fel. Ez a tény is - a kétnyelvű életbe léptető rendelet mellett - azt látszik megerősíteni, hogy a kodifikáció középpontjában a Digesta állt, és igazán újat ennek a gyüjteménynek a megalkotása jelentett. ${ }^{18}$

A bevezető rendeletek különösen a szóképek burjánzásában tűnnek ki a jogi szövegek között, ugyanakkor a páratlan díszítettség mellett sokszor találkozunk kimondottan technikus jellegű utasításokkal (különösen az Omnem és a Deo auctore bővelkedik ilyenekben). ${ }^{19}$ A továbbiakban a bevezető rendeletek szövegében megtalálható, a ius-

17 Shepard: i. m. (1. jegyz.) 106.

${ }^{18}$ Császári rendeletek gyűjteményei nem Iustinianus idején kerültek először kibocsátásra, mert a jog megismerhetőségére vonatkozó igény az egész posztklasszikus kor sajátja, amelyet Pólay az ún. stabilizációs jogtudomány eredményének tart. Ennek keretében több császári rendeletgyűjtemény állt rendelkezésre már a III. század végétől, így a Codex Gregorianus, Codex Hermogenianus és különösen a 438-ban keletkezett Codex Theodosianus. Lásd Pólay E.: A római jogászok gondolkodásmódja. Budapest 1988. 174-175.

19 Terjedelmi okokból valamennyi szókép vizsgálatától eltekintek, e helyütt viszont felsorolás szintjén jelzem, hogy a nyolc rendeletben milyen szóképek fordulnak elő. Metaforák: Deo auct. 5 (falmetafora és templommetafora); Tanta 11 és 20 (templommetafora); hasonlatok: pl. Imp. 1 (quasi per medium profundum euntes); allegória: Deo auct. 1; Omnem 2 („út”-allegória); Ilias-allúzió: Omnem 11. Gyakoriak a következők: idősíkváltás pl. Tanta 18; megszemélyesítés pl. Tanta 10; ismétlések, főleg a hendiadyoin pl. Imp. 1, Deo auct. 7; hysteroproteron például Imp. 1. Szintén általános eszköz a különböző nagyítások és túlzások, valamint a felsőfok elativusi használata. 
tinianusi törvényművekre vonatkozó metaforákkal kívánok foglalkozni, előrebocsátva, hogy azok szignifikáns mértékben a kodifikáció keresztény jellegének ecsetelését voltak hivatottak szolgálni.

Iustinianus kodifikációs és hódító szándéka mint kettős birodalmi célkitűzés szinte valamennyi bevezető rendelet praefatiójában megjelenik, de mind közül talán a legkifejezőbb az Imperatoriam elején szereplő alábbi szöveghely: ${ }^{20}$

Imperatoriam maiestatem non solum armis decoratam, sed etiam legibus oportet esse armatam, ut utrumque tempus et bellorum et pacis recte possit gubernari et princeps Romanus victor existat non solum in hostilibus proeliis, sed etiam per legitimos tramites calumniantium iniquitates expellens, et fiat tam iuris religiosissimus quam victis hostibus triumphator. (Imperatoriam pr.)
A császár felségét nemcsak fegyverekkel kell feldíszíteni, de törvényekkel is fel kell fegyverezni azért, hogy képes legyen helyesen kormányozni mind háború idején, mind béke idején, és a római princeps ne csak az ellenséggel vívott csatákban váljon győzedelmessé, hanem annak révén is, hogy a hamisan perlekedők visszaéléseit törvényes úton szüntesse meg, és legalább annyira legyen a jog betartatója, mint amennyire a legyőzött ellenség felett triumfáló hadvezér. ${ }^{21}$

A praefatio első sora párhuzamosan szerkesztett, és egy enallagét rejt magában: armis decoratam és legibus armatam. A rendelet szövegében szerepelhetne armis armatam (figura etymologica) és legibus decoratam is, de a jelzőcsere még egy díszt jelent, ami nem véletlen, hiszen így keretbe foglalja a kettős célt, az olvasó szemét az armis ... armatam kifejezésekre és a köztük lévő részre irányítva. Ezt követően a rendelet a két elérendő cél szerepét is hangsúlyozza, hiszen egyrészről a felfegyverzett császár az, aki háború idején helyesen tud kormányozni, és a törvényekkel ékesített császár az, aki béke idején a társadalmi rend és biztonság fenntartója. ${ }^{22}$

${ }^{20}$ Ugyanezt a gondolatot hangsúlyozza a Summa pr. (Summa rei publicae tuitio de stirpe duarum rerum, armorum atque legum veniens), továbbá általánosságban a Deo auctore pr. és a Tanta pr. A gondolat nemcsak Iustinianus rendeleteiben köszön vissza, hanem megtalálható a Gesta senatus Romani de Theodosiano publicandóban is: per vos arma per vos iura (lib. I). A keleti birodalomfél uralkodói e két eszközre mint a római birodalom integrációjának eszközére tekintettek. Lásd részletesen $L$. Atzeri: Gesta senatus Romani de Theodosiano publicando. Il Codice Teodosiano e la sua diffusione ufficiale in Occidente. Berlin 2008. 15-16.

${ }^{21}$ A rendelet folytatásában hangsúlyozza, hogy Isten útmutatásával sikerült ezt a két célt megvalósítani, mert egyrészt a barbár népeket csatákban leigázták, így Afrikát is visszahódították, valamint valamennyi nép Iustinianus törvényeinek megfelelően él (Imp. 1.). Lásd ehhez még Sarris: i. m. (9. jegyz.) 5.

${ }^{22}$ Ekként a fentebb már idézett Summa pr: Summa rei publicae tuitio de stirpe duarum rerum, armorum atque legum veniens... Hasonlóra utalhat az ... et statum rei publicae sustentamus ... (Deo auctore pr.). A salus rei publicae gondolata már a köztársaság korától kezdődően jelen van a római gondolkodásban. A biztonság mint metafora több helyen felbukkan a római irodalom történetében, így az Augustus-kori költészetben is (ehhez részletesen lásd M. Lowrie: Le salut, la sécurité et le corps du chef: transformations dans la sphère publique à l'époque d'Horace. In: B. Delignon - N. Le Meur - O. Thévenazl [eds.]: La poésie lyrique 
Az utolsó sor ismét egy párhuzamos szerkesztés, amely ezúttal a triumphator jelzőjeként adja meg, hogy egyrészt iuris religiosissimus, másrészt victis hostibus legyen diadalmas. A religiosus superlativusa itt olyan emberre utal, aki messzemenően betartja a vallás előírásait, emellett uralkodóról lévén szó, egyszersmind be is tartatja. ${ }^{23}$ Egy fegyelmezett uralkodó képe jelenik meg, aki ezt a fegyelmezettséget nem csupán a vallás, hanem a jog terén is gyakorolja. A iuris religiosissimus jelző azt juttatja kifejezésre, hogy a jogot legalább annyira tiszteletben tartja és betartatja, ahogyan a vallás szabályait. Ez Iustinianusszal összefüggésben egyedi jelző, amely nyomatékosan fejezi ki azt az elképzelést, hogy a császár számára mindkét birodalmi cél, a hódítás és a jogalkotás Isten adta feladatok. ${ }^{24}$ Söt a religiosissimus még ennél is többet jelenthet, hiszen Iustinianus nem pusztán a kodifikációt rendelte el, de igen nagy számban hozott vallási tárgyú rendeleteket, és törvényi szabályozás útján törekedett a keresztény vallás megszilárdítására. Az uralkodó religiosissimus jelzője tehát már magában rejti a keresztény kodifikáció gondolatát.

Ez különösen jelentős abból a szempontból, hogy Iustinianusnál az uralkodó személye már a keresztény interpretációnak megfelelően az alattvalók vallási életének középpontjában helyezkedik el. A római császári hatalom keresztény víziója szerint, ahogyan a császár szolgálja Istent, úgy szolgáják alattvalói őt magát. Saját restaurációs programját is Isten megelégedésére készítette el, hiszen rendeleteiben saját magáról is úgy nyilatkozik, mint aki jogalkotó hatalmát az Úrtól nyerte. ${ }^{25}$ Erre legszemléletesebben az a megállapítás utal, miszerint a kodifikáció emberfeletti feladatára csak Isten útmutatásával kerülhetett sor, miként a csatákban is Isten segítségével győzedelmeskedett:

A bevezető rendeletekben az ilyen fordulatok ${ }^{26}$ legtöbbször a deus szó különböző alakjaival alkotott szókapcsolatokban érhetők tetten, ugyanakkor ettől eltérő megfogalmazások is találhatók.

dans la cité antique. Les Odes d'Horace au miroir de la lyrique grecque archaïque. Actes du colloque organisé les 6-8 juin 2012 par l'ENS de Lyon. 71-86.) A római jog ebben a folyamatban mint a múlt kontiniutásának megőrzője („legislation as vehicle / as medium” lásd Ch. Pazdernik: Justinianic Ideology and the Power of the Past. In: M. Maas [ed.]: The Cambridge Companion to the Age of Justinian. Cambridge 2005. 188 és 191) jelenik meg.

${ }^{23}$ A religio Köves-Zulauf által bevezetett jelentése ebben a kontextusban még erőteljesebben beleérthető a jelzőbe. Köves-Zulauf szerint a rómaiak vallása a félelem, elfojtottság vallása, szemben azzal a felszabadult feloldódással, amely a görög vallás jellemzője. „A religio embere gondosan megválogatja, mely tartalmakat enged a felszínre kerülni; félelme csak fegyelme másik oldala, mellyel felszín és mélység egyensúlyát fenntartja." Lásd Th. Köves-Zulauf: Bevezetés a római vallás és monda történetébe. Budapest 1995. 144.

${ }^{24}$ A. D. Lee: The Empire at War. In: M. Maas (ed.): The Cambridge Companion to the Age of Justinian. Cambridge 2005.113-133.

${ }^{25}$ Maas: i. m. (1. jegyz.) 21-23; Sarris: i. m. (9. jegyz.) 206 skk. Lásd még részletesen Sáry: i. m. (16. jegyz.) 207 skk.

${ }^{26}$ Wallinga az Ebrard által Devotionsfloskelnek nevezett ezen kifejezések kapcsán megjegyzi, hogy itt ennél többről van szó, mivel az általa vizsgált Tanta vonatkozásában ezek azt hangsúlyozzák, hogy az uralkodó csak eszköze az isteni gondviselésnek. Részletesen lásd T. Wallinga: Tanta/ $\Delta \varepsilon \delta \omega \kappa \varepsilon v$ : Two Introductory Constitutions to Justinian's Digest. Groningen 1989. 58. Wenger hozzáteszi, hogy nem csupán a rendeletek principiumaiban, hanem a bevezető rendeletekben szinte végig megtalálhatóak. Lásd Wenger: i. m. (3. jegyz.) 580. 


\begin{tabular}{|c|c|c|}
\hline Kifejezés jelentéssel & $\begin{array}{c}\text { Előford. } \\
\text { száma }\end{array}$ & Előfordulási helyek \\
\hline Deo auctore ('Isten jóváhagyásával') & 1 & Deo auctore pr. \\
\hline Deo propitio ('Isten segítségével') & 4 & $\begin{array}{l}\text { Deo auctore 10; Tanta 9; } \\
\text { Imperatoriam 3; Summa } \\
\text { pr. }\end{array}$ \\
\hline adnuente Deo ('Isten jóváhagyásával') & 3 & \begin{tabular}{|l|} 
Deo auctore $12 ;$ Tanta \\
21; Imperatoriam 1 \\
\end{tabular} \\
\hline $\begin{array}{l}\text { Deique omnipotentis providentiae / ad Dei omnipotentis } \\
\text { erigimus adiutorium omnipotenti Deo / auxilio dei } \\
\text { omnipotentis ('a mindenható Isten gondviselésének' / 'a } \\
\text { mindenható Isten segedelmébe vetjük bizadalmunkat' / 'a } \\
\text { mindenható Isten segítségével') }\end{array}$ & 4 & $\begin{array}{l}\text { Deo auctore pr., 14; } \\
\text { Tanta 12; Haec q.n. pr. }\end{array}$ \\
\hline summa numinis liberalitate ('Isten legfóbb jóakaratából') & 1 & Deo auctore 5 \\
\hline $\begin{array}{l}\text { divinae humanitatis providential ('az isteni emberiesség- } \\
\text { nek gondviselése') }\end{array}$ & 1 & Tanta pr. \\
\hline $\begin{array}{l}\text { caelesti fulgore et summae trinitatis favore ('Isten fényével } \\
\text { és a legfóbb szentháromság kedvezésével') }\end{array}$ & 1 & Tanta 1 \\
\hline $\begin{array}{l}\text { ad solam referamus summae prouidentiam trinitatis } \\
\text { ('a legföbb szentháromság egyedüli gondviselésébe he- } \\
\text { lyezzük') }\end{array}$ & 1 & Deo auctore pr. \\
\hline Deo placido ('Isten tetszése szerint') & 1 & Deo auctore 14 \\
\hline Dei gubernatione ('Isten vezetésével') & 1 & Omnem 11 \\
\hline $\begin{array}{l}\text { Domino et Deo Nostro Ihesu Christo / maximi dei et } \\
\text { domini nostri Ihesu Cristi ('a Mi Urunk és Istenünk Jézus } \\
\text { Krisztus [segítségével]') }\end{array}$ & 3 & $\begin{array}{l}\text { Tanta pr., } 23 \\
\text { imperatoriam címzése }\end{array}$ \\
\hline $\begin{array}{l}\text { caelestis ... providentiae / numine caelesti ('Isten gondvi- } \\
\text { selése/jóváhagyása által') }\end{array}$ & 2 & Tanta pr. \\
\hline $\begin{array}{l}\text { Deo praesule prono animo nos dedidimus ('átadtuk ma- } \\
\text { gunkat egy Isten élenjárásának engedelmes lélekkel') }\end{array}$ & 1 & Summa 1 \\
\hline omnia caelestia dona ('valamennyi égi adomány') & 1 & Tanta 23 \\
\hline summae divinitati ('a legfőbb Isten számára') & 1 & Tanta 19 \\
\hline
\end{tabular}

Ezen kifejezésekben tehát olyan alapvető keresztény fogalmak, mint a gondviselés (providentia), Szentháromság (Trinitas) is megjelennek vegyesen a pogány eredetü római utalásokkal, mint amilyen a caelesti numine ${ }^{27} \mathrm{~A}$ keresztény utalások célja pedig a császári ideológia megerősítése, és ezzel összefüggésben a keresztény szellemben végrehajtott kodifikáció szentesítése. ${ }^{28}$

Ezt tovább erősíti, hogy ezen kifejezések mellett a metaforák közt is akad egy olyan, amely kifejezetten a templomépítő Iustinianus képét tárja az olvasó elé. Ezzel pedig nem

27 Ovidius kedvelt kifejezése, lásd például Ov. Met. 14, 594.

${ }^{28}$ Ez kifejezésre jut Iustinianus 6. novellájában (535) is, amely szerint: Maxima quidem in hominibus sunt dona dei a superna collata clementia sacerdotium et imperium, illud quidem divinis ministrans, hoc autem humanis praesidens ac diligentiam exhibens ... A novella részletes elemzéséhez lásd Shepard: i. m. (1. jegyz.) 108-109. 
mást akart hangsúlyozni, mint hogy a bibliai Salamonhoz és Heródeshez hasonlóan neki is célja volt templomot építeni, hogy az a - rendeleteiben kizárólagossá tett - keresztény vallás gyakorlásának színteréül szolgáljon. Ez a templom nem más, mint az 532-es Nika-lázadásban leégett Hagia Sophia templom, amelyet 532-537 között építettek újjá. Iustinianus ugyanakkor nemcsak fizikai értelemben emeltetett templomokat, hanem törvénykönyvei közül a jogtudósi vélemények kincsesházának szánt Digestát is meglepő tudatossággal komponálta meg. Ez egyrészt megnyilvánul a Digesta egészének elrendezésében, másrészt a Digestának mint az igazságosságnak szentelt templomnak a metaforájában.

A számszimbolika fontosságára a Digesta kapcsán elsőként Franz Hofmann Die Compilation der Digesten Iustinians című monográfiájában, majd Rolf Knütel Christliche Zahlensymbolik im Digestenplan címü tanulmányában hívta fel a figyelmet. E kérdésre csak röviden - az alábbiakban elemzésre kerülő templommetaforához kapcsolódóan szükséges mértékig - térek ki.

Iustinaianus föltehetőleg hitt a számmisztikában, emellett Tribonianus személyében - Hofmann szerint - olyan kivitelezőre lelt, aki értett is a számmisztikához és asztrológiához. ${ }^{29}$ A kodifikáció valamennyi törvénymüve egyetlen harmonikus összeállítás részeként - a keresztény számmisztika alkalmazásával ${ }^{30}$ - jött létre, amelyek közül a $D i$ gesta elrendezése a legtudatosabb, ahogy annak a Tanta kezdetű rendelet hangot is ad: ${ }^{31}$

... Nomenque libris imposuimus digestorum seu pandectarum, ${ }^{32}$ quia omnes disputationes et decisiones in se habent legitimas et quod undique fuit collectum, hoc in sinus suos receperunt, in centum quinquaginta paene milia versuum ${ }^{33}$ totum opus consummantes. Et in septem partes eos digessimus, non perperam neque sine ratione, sed in numerorum naturam et artem respicientes et consentaneam eis divisionem partium conficientes. (Tanta 1)
És a könyvek számára a Digesta seu Pandectae nevet irányoztuk elő, mivel magában foglalja valamennyi, a törvényekhez tartozó értekezést és jogi döntést, valamint mindazt, amit mindenhonnan összegyüjtöttek, és keblükre öleltek a csaknem százötvenezer sornyi teljes mű elkészítői. És azokat hét részre osztottuk, nem helytelenül, és nem megfontolás nélkül, hanem számításba véve számuknak természetét és tulajdonságát, és az egyes részeknek következetes felosztást készítvén.

${ }^{29}$ F. Hofmann: Die Compilation der Digesten Iustinians. Wien 1900. 193. Az ókoriak gondolkodásában a számmisztikának jelentősége volt, mivel az ókori ember egészen más szerepet tulajdonított ennek, mint a modern kor embere, ugyanakkor a számszimbolikát mindig kellő szkepszissel érdemes megközelíteni.

${ }^{30}$ R. Knütel: Christliche Zachlensymbolik im Digestenplan. ZSSR 113 (1996) 422-430.

${ }^{31}$ Knütel: i. m. (30. jegyz.) 422-423; Hofmann: i. m. (29. jegyz.) 192-193.

32 A Digesta görögös elnevezése: Pandectae a $\pi \tilde{\alpha} v \delta \varepsilon ́ \chi \varepsilon \sigma \theta \alpha \imath$ 'mindent átfogni' kifejezésre utal, amely jól tükrözi, hogy valóban az egész régi jog anyagát sikerült összegyűjteni, és egyetlen kódexben elrendezni (megjegyzendő mindazonáltal, hogy a pandectae műfaj már a korai császárkorban ismert volt). Vö. FöldiHamza: i. m. (1. jegyz.) 96.

${ }^{33}$ A rendelet szövege a Digesta sorairól sokszor versusként tesz említést, mintegy verssorként hivatkozva a jogtudományi munkák soraira. 


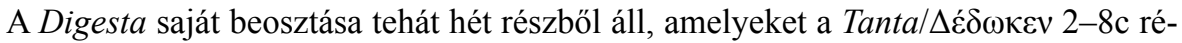
szek tárgyalnak részletesebben, amelyek hozzávetőlegesen utalnak arra is, hogy milyen jogintézmények tartoznak az egyes parsokba. Az elrendezés a következő: ${ }^{34}$

\begin{tabular}{|c|c|c|c|c|c|}
\hline Pars & Tanta & Nomen partium & Numerus & Libri numeri & \\
\hline Pars I & 2 & $\pi \rho \tilde{\omega} \tau \alpha$ & $1-4$ & 4 & elementa \\
\hline Pars II & 3 & de iudiciis ${ }^{4}$ & $5-11$ & 7 & \\
\hline Pars III & 4 & de rebus & $12-19$ & 8 & \\
\hline Pars IV & 5 & $\mathrm{X}$ singularium libri & $20-27$ & 8 & 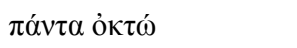 \\
\hline Pars V & 6 & $\begin{array}{l}\text { VII de legatis et } \\
\text { fideicommissis }\end{array}$ & $28-36$ & 9 & \\
\hline Pars VI & 7 & $\begin{array}{l}\text { II de bonorum } \\
\text { possessionum }\end{array}$ & $37-44$ & 8 & \\
\hline Pars VII & 8 & & $45-50$ & 6 & harmonia ac perfectio \\
\hline
\end{tabular}

A Digesta elrendezésénél a következő számok bírnak különleges jelentőséggel: négyes, hatos, hetes és nyolcas. ${ }^{36}$

Az első rész, amelyet $\pi \rho \tilde{\tau} \tau \alpha$-nak neveznek 4 könyvből áll, a Digesta könyvei közül a legelemibb tudást foglalja magában. A négyes szám a dolgok alapját, gyökerét jelenti, így az egész természet forrását szimbolizálja, ${ }^{37}$ és ez pedig a Deo auctore alapján nem más, mint a Szentháromság. ${ }^{38}$ Nem véletlen, hogy az elsőéves jogtanulók számára ez volt a tananyag az Institutiones címü tankönyvvel együtt, amely szintén négy könyvből áll. ${ }^{39}$ A négyes szám tehát a mindenség elemeit, itt közelebbről pedig a jog elemeit szimbolizálja. Emellett keresztény kontextusban a négyes szám az evangéliumokra utal.

Hofmann, és az ő nézetét követve Knütel is kiemli, hogy a nyolcas szám, amely a mindenség harmóniáját szimbolizálja, ${ }^{40}$ valamint a megújulást jelenti, ${ }^{41}$ különleges szerepet kap annak révén, hogy a Digesta közepén elhelyezkedö pars IV éppen ennyi könyvből áll. ${ }^{42}$ Knütel szerint itt helyezkednek el a legkiválóbb jogtudósi vélemények, ${ }^{43}$ ez a mü egészének középpontja, amire a Tanta/ $\Delta \varepsilon \dot{\delta} \omega \kappa \varepsilon v 5$ a köldök hasonlattal utal

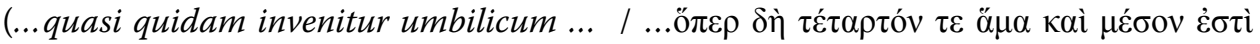

34 Jelen táblázat nagyrészt a Knütel által közölt táblázaton alapul. Lásd Knütel: i. m. (30. jegyz.) 423.

35 Ennek a résznek és az azt képező hét könyv jelentésének értelmezéséhez lásd Hofmann: i. m. (29. jegyz.) 196.

${ }^{36}$ Hofmann részletesen foglalkozik továbbá még a hármas és a tizenkettes szám jelentésével is, Knütel pedig a tizenhetessel és az ötvenessel. Lásd Hofmann: i. m. (29. jegyz.) 189 és 193-194. Knütel: i. m. (30. jegyz.) 429-430.

37 Hofmann: i. m. (29. jegyz.) 190 és 194.

38 Vö. Deo auctore pr: omnem spem ad solam referamus summae providentiam trinitatis: unde et mundi totius elementa processerunt et eorum dispositio in orbem terrarum producta est.

39 Hofmann: i. m. (29. jegyz.) 194.

40 Ekként Hofmann: i. m. (29. jegyz.) 196.

41 Ekként Knütel: i. m. (30. jegyz.) 427.

42 Hofmann: i. m. (29. jegyz.) 197.

43 Knütel: i. m. (30. jegyz.) 430. 


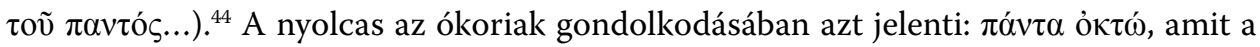
görögök közmondásszerűen arra használtak, ha valaminek tökéletességét és nagyszerü voltát akarták hangsúlyozni. ${ }^{45}$

A hetedik rész ${ }^{46}$ amellyel a Digesta lezárul hat könyvből áll. Mind a hetes és a ha-

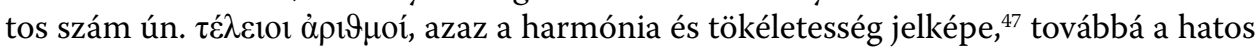
szám szerencsehozó szám is. ${ }^{48}$ A hetes szám, vagy numerus Pythagoraeus a pythago-

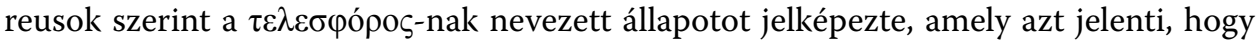
'tökéletességbe menetel.' Ennélfogva a hetes szám a tökéletesség és teljesség szimbóluma. Továbbá a Bibliában kiemelkedő szerepe van a hetes számnak, a világ teremtésétől egészen a Jelenések Könyvéig. ${ }^{49}$

A Digesta mellett a kodifikáció egészét a hármas szám fémjelzi, amennyiben három törvényművet hoztak létre, nevezetesen az Institutiones, a Digesta és a Codex hármasságát, ${ }^{50}$ kis túlzással három év alatt, ahogyan a Tanta 12 fogalmaz (...in tribus voluminibus ... perfecta et in tribus annis consummata ...). ${ }^{51}$ A hármasság pedig - gondolva a Szentháromságra - a legjobb kifejezése talán az Isten útmutatásával végzett kodifikációnak.

Ehhez a számmisztikához társul egy különös metafora, amely a Digestát iustitiae templumként írja le. A kép három helyen jelenik meg: Deo auctore 5, Tanta 11 és 20. A Digestához kapcsolódó rendeleteken végigvonuló allegória a Digestát mint egy templomot ábrázolja.

A Digesta összeállítását elrendelő Deo auctore vezeti fel ezt a képet először egy hasonlat formájában:

Cumque haec materia summa numinis liberalitate collecta fuerit, oportet eam pulcherrimo opere extruere et quasi proprium et sanctissimum templum iustitiae consecrare et in libros quinquaginta et certos titulos totum ius digerere... (Deo auctore 5)
És miután ez az anyag Isten legfőbb jóakaratából össze lesz majd állítva, akkor kell azt igen nagy mügonddal megépíteni, és mintegy az igazságosságnak saját és legszentebb templomaként felszentelni, és ötven könyvben és meghatározott [számú] fejezetekben az egész jogot elrendezni ...

44 Wenger: i. m. (3. jegyz.) 581; Wieacker: i. m. (8. jegyz.) 296.

45 Johannes Meursius XVI. századi holland ókortudós művét idézi Hofmann: i. m. (29. jegyz.) 196.

46 A Digesta első könyvétől a hetedik rész végéig összesen ötvenet tesz ki a törvénymű könyveinek száma. A kezdettől fogva tervezett ötven könyv darabszáma a keresztény szimbolikában azt az 50 napot je-

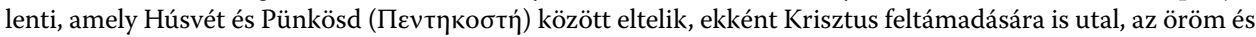
boldogság szimbólumaként. Ennek részletes tárgyalását lásd Knütel: i. m. (30. jegyz.) 427.

47 Hofmann: i. m. (29. jegyz.) 195.

48 Hofmann: i. m. (29. jegyz.) 196.

49 Hofmann: i. m. (29. jegyz.) 191; Knütel számos párhuzamot hoz a Biblia alapján, így említi a Jelenések könyvét, Jerikó lerombolását és a frigyláda körbehordozását a város körül, a Dekalóg első három parancsolata utáni hetességet és különösen a Teremtés történetét, hozzátéve, hogy a hetes szám nem csupán a szentségek, de a béke szimbóluma is. Lásd Knütel: i. m. (30. jegyz.) 425-426.

${ }^{50}$ Hofmann: i. m. (29. jegyz.) 189.

51 Vö. Omnem 7 és Tanta 23; lásd még részletesen Hofmann: i. m. (29. jegyz.) 189-190. 
A szövegben ismét találunk egy utalást arra, hogy a kodifikáció nem sikerülhetett volna Isten segítsége nélkül, és az első sor azt is jól mutatja, hogy ennek a roppant műnek az összeállítására két lépcsőben került sor, először a klasszikus jogtudósok müveinek kiválogatásával és elolvasásával, majd a Digesta elrendezésével. A császár pedig elrendelte, hogy a kompilátorok úgy rendezzék el a Digestát ötven könyvben, mintha az igazságosságnak szentelnének templomot: ... et quasi proprium et sanctissimum templum iustitiae consecrare ... (Deo auctore 5). Ezen utasítást követően a Deo auctore számos igen gyakorlatias utasítást tartalmaz arra nézve, hogyan kell összeállítani a müvet. Felmerülhet a kérdés, hogy vajon itt Iustitia istennőnek szentelt templomról lenne-e szó, vagy pedig az isteni igazságosságnak szentelt templomról. Úgy gondolom, hogy a keresztény kodifikáció gondolata önmagában is az utóbbi felé billenti a mérleget, de ebben a szakaszban külön említi is a rendelet szövege, hogy Isten legföbb jóakaratának köszönhető a törvénykönyv anyagának összegyüjtése, azaz a metaforánál maradva, a templom építőköveinek összeállítása.

A Deo auctore tehát a Digestát mint az igazságosság templomát rendelte megkomponálni, amelyre három év alatt sor is került, majd ezt követően 533. december 16-án Iustinianus a Tantával hatályba is léptette. A Tanta kezdetü rendelettel a Digesta elrendezésére utaló előbbi mondatát a hét rész részletes leírása követi a Tanta 2-8c-ig tartó részben, ahol röviden az egyes részek tartalmát határozza meg a rendelet. ${ }^{52}$ Ennek a száraz, szinte kizárólag jogi technikus szövegnek a közepén a következőt olvashatjuk a Tanta 6b-ben:

Sed in his nihil de caducis a nobis memoratum est, ne causa, quae in rebus non prospere gestis et tristibus temporibus Romanis increbuit calamitatibus, bello coalescens civili, nostris remaneant temporibus, quae favor caelestis et pacis vigore firmavit et super omnes gentes in bellicis victoriis posuit, ne luctuosum monumentum laeta saecula inumbrare concedatur.

(Tanta 6b)
De ezekben [ti. a hagyományokról szóló részekben] nem emlékezünk meg a $c a$ ducumokról, nehogy a polgárháborúhoz kapcsolódó emlék (vagy: polgárháborúval egybefonódott jogintézmény), amely a kedvezőtlenül alakuló események közepette és szomorú időkben a rómaiak viszontagságai között elharapódzott, a mi időnkben is fennmaradjon, amelyet az égiek kedvezése a béke elevenségével megerősített, és amelyet háborús győzelmekkel valamennyi nemzet fölé helyezett, [tehát] hogy ne engedtessék meg az, hogy gyászos emlékmü (vagy: gyászos emlékezetü jogintézmény) árnyékolja be a boldog századokat.

${ }^{52}$ Az Omnem 1 leírja a régi tanrendet, jelezve, hogy az nem megfelelő, majd az Omnem 2 leírja a követendő tanmenetet is. Knütel egybeveti a Digesta 7 részét az Omnemben közölt tantervvel. Ehhez részletesebben lásd Knütel: i. m. (30. jegyz.) 423. 
A bekezdés a Tanta 5-6 után szerepel, ahol a - római jogtudósok által bizonyos értelemben a legfontosabb matériának tekintett - öröklési jog intézményei közül a végrendeletre és a kapcsolódó szabályokra történik utalás. Itt kerül szóba, hogyan értendő, hogy a Digesta vonatkozó titulusa nem emlékezik meg a caducumokról. Ha az értő olvasó az előbbi négy bekezdésnyi - végrendeletekről szóló - jogi szakszöveg után ehhez a részhez ér, meglepőnek találhatja a fordulatot. A caducum ugyanis technikus értelemben a végrendeleti öröklésnél az ún. elesett örökrészt jelenti, ${ }^{53}$ amelyet a végrendeleti örökös nem tud megszerezni gyermektelensége vagy házasulatlansága folytán (a iustinianusi jogban ezek az esetek megszűnnek), ${ }^{54}$ hasonlóképpen az erkölcstelen életvitelü nők sem szerezhetik meg a végrendeleti örökséget. ${ }^{55}$ De miért ne tárgyalhatná a Digesta vonatkozó titulusa ezt a jogintézményt?

Az új német Digesta-fordítás ${ }^{56}$ a caducumon a technikus jogi értelemben felfogva minden olyan vagyont ért, amely az államra száll (ún. res vacans). ${ }^{57}$ Ezzel szemben azonban egy olyan jogi értelmezés is adható, miszerint a caducum egyes eseteinek eltünését látjuk, így a gyermektelenség vagy házasulatlanság miatti szerzésképtelenségi ok megszűnését. Ezen interpretáció mellett egy további lehetőség is felvethető, miszerint a jogintézménnyel egy időben visszaéltek, ti. a polgárháborúk során mások vagyonának konfiskálásával, mások életének kárára jutottak egyesek „aránytalan előnyhöz”. ${ }^{58}$ Wallinga hasonló nézetet képvisel, kifejti továbbá, hogy az inumbrare egy fény-árnyék játék érzését kelti az olvasóban, ahol a fény a dicső jelent, a sötétség pedig a gyászos múltat jeleníti meg. ${ }^{59}$

Ugyanakkor a caducum esetén másra is gondolhatunk, mégpedig a 'mulandó dolgokra'60 A 6b-ben a rendelet szövege egy zseniális szójáték után megidézi számunkra a római történelem viharos évszázadait, így a polgárháború keserü emlékét, de végül is a béke és a dicső győzelem feledteti ezt velünk. A polgárháború itt két eseményre is utalhat egyszerre, egyrészt szimbolikusan felidézi az olvasóban a Caesar és Pompeius közti

${ }^{53}$ Lásd E. Seckel: Heumanns Handlexikon zu den Quellen des römischen Rechts. Jena $1907^{9}$ (a továbbiakban: HS) caducum szócikk 2. jelentés; OLD 10. jelentés. Vö. még ThLL: caducus.

${ }^{54}$ E jogintézményhez lásd részletesen M. Kaser: Das römische Privatrecht. Bd 1. München 19711975². 320 sk és 724 skk, Bd 2: 532 skk; Földi-Hamza: i. m. (1. jegyz.) 612.

${ }^{55}$ A iustinianusi jogban ez marad a caducum egyetlen esete (FH, 612). Vö. Tryphon. Dig. 29, 1, 41, 1: Mulier, in qua turpis suspicio cadere potest, nec ex testamento militis aliquid capere potest, ut divus Hadrianus rescripsit.

56 Behrends és kollégiának fordításában a caducum 'Erbgut das dem Staat verfällt' (lásd O. Behrends - R. Knütel - B. Kupisch - H. Seiler [Hrsg.]: Corpus Iuris Civilis. Text und Übersetzung III. Digesten 11-20. Heidelberg 1999. 77).

57 Lásd HS caducum szócikk 3. jelentés.

${ }^{58} \mathrm{Ez}$ az értelmezés olvasható ki a szövegből, ha figyelembe vesszük a Georges-szótár felvetését. Lásd Georges szótár 1) B alatti jelentés (K. E. Georges: Ausführliches lateinisch-deutsches Handwörterbuch. Bd. 1. Darmstadt 1913. 893-894); vö. Gai. Dig. 29, 5, 9 és Paul. Dig. 29, 6, 2, 2. Vö. még ThLL s. v. caducus. Lényegében erre az értelmezésre jut Wallinga: i. m. (26. jegyz.) 58. és 62.

59 Wallinga: i. m. (26. jegyz.) 62.

${ }^{60}$ Lásd OLD 1-5 jelentések és Georges 1) A és 2) jelentések. 
polgárháborút (netán előzményként a Sulla és Marius közti ellentéteket), de egyszersmind a Digesta összeállításának idejére eső, 532 januárjában zajló Nika-felkelés igen közeli emlékét is. ${ }^{61}$ A rendelet $6 b^{62}$ szakasza emlékezteti olvasóját arra, hogy ezen szomorú események megtörténtek ugyan, de most birodalomszerte béke ragyog, így nem kell a múlt gyászos emlékmüvére gondolni. ${ }^{63}$ Még konkrétabban a Nika-felkeléssel összefüggésben - ahol megkérdőjelezték alattvalói a császár politikáját ${ }^{64}$ - Iustinianus éppen arra törekedett, hogy a számára kellemetlen eseményeket feledtesse, és ezt katonai sikereinek említésével igyekezett elérni. ${ }^{65}$ Iustinianus tudatosan az augustusi mintához tér vissza, és propagandája is ezt tükrözi. ${ }^{66} \mathrm{Ez}$ a határtalan optimizmus - amely még jóval az itáliai hadjárat különböző kudarcai előtt jellemzi Iustinianust - Augustus korának, mint egy polgárháborút követő „aranykornak” az emlékét idézheti fel az olvasóban.

Ezen kitérő után a Tanta 11-ben ismét visszatér a templomképhez, és ezúttal a templomot szemléletesen meg is jeleníti számunkra:

Sed cum prospeximus, quod ad portandam tantae sapientiae molem non sunt idonei homines rudes et qui in primis legum vestibulis stantes intrare ad arcana eorum properant, et aliam mediocrem eruditionem praeparandam esse censuimus, ut sub ea colorati et quasi primitiis omnium imbuti possint ad penetralia eorum intrare et formam legum pulcherrimam non coniventibus oculis accipere.

(Tanta 11)
De minthogy elöre láttuk, hogy képzetlen emberek nem lehetnek alkalmasak ilyen nagy tudomány müvének megértésére, és [azok sem], akik a törvények elöcsarnokának bejáratában állván belépni készülnek annak belsejébe, úgy véltük, hogy el kell készíteni egy másik, szerényebb méretü tankönyvet is, hogy azzal feltöltekezve, mintegy az egész alapjait megismervén léphessenek be annak [ti. templomnak] belsejébe, és a törvények legszebb megjelenését ne hunyorgó szemekkel fogadják be.

${ }^{61}$ A. Guarino: Storia del diritto romano. Napoli $1998^{12} \cdot 587-588$.

${ }^{62}$ Emlékezéssel, emlékezettel kapcsolatos további forráshelyek a Tanta 6b mellett a Tanta 11; Tanta 13; Deo auctore 14; Omnem 4, valamint a Cordi nobis 4.

${ }^{63}$ A monumentum szó nemcsak a korábbi korok gyászos emlékeire utal, hanem a szó jelent 'síremléket' is, és mint olyan legjobban Horatius 3, 30-as ódájának első sorából ismert: exegi monumentum aere perennius (Hor. carm. III 30, 1)

${ }^{64}$ Iustinianus ugyanakkor profitált is a felkelésből, mivel azt a tényt, hogy ő maga túlélte a lázadást, úgy tekintette, mint az isteni támogatás jelét. Lásd Maas: i. m. (1. jegyz.) 7.

${ }^{65}$ Az emlékezet irányítása általában nem hiányzik a császárok eszköztárából, és Iustinianus esetében is nagyban hozzájárult ahhoz, hogy tetteiről és saját magáról kialakult képet befolyásolhassa. A polgárháború egészének és az abban résztvevők emlékének törlése - vö. damnatio memoriae - is része volt Iustinianus propagandájának. Az emlékezet irányításához részletesen lásd A. M. Gowing: Empire and Memory: The Representation of the Roman Republic in Imperial Culture. Cambridge 2005. 2 skk; J. Assmann: Cultural Memory and Early Civilization. Writing, Remembrance, and Political Imagination. Cambridge 2011. 54 skk.; továbbá Pazdernik: i. m. (22. jegyz.) 186.

${ }^{66}$ Assmann: i. m. (65. jegyz.) 17 sk. 
Valamint az Index auctorum összeállításának elrendelésénél is:

Ne autem incognitum vobis fiat, ex quibus veterum libris haec consummatio ordinata est, iussimus et hoc in primordiis digestorum nostrorum inscribi, ut manifestissimum sit, ex quibus legis latoribus quibusque libris eorum et quot milibus hoc iustitiae Romanae templum aedificatum est.

(Tanta 20)
Azért pedig, hogy ne váljon számotokra ismeretlenné, hogy a régiek melyik könyveiből lett ez az összegzés elrendezve, megparancsoltuk, hogy ezt írják bele $D i$ gestánk legelejére, azért hogy nyilvánvaló legyen, melyik jogtudóstól és azoknak melyik könyvéből, és hány ezerből épült meg az igazságosság ezen római ${ }^{67}$ temploma.

A Tantában a törvénykönyv mint „templom” jelenik meg, a benne rejlő szöveg (a jogtudósok véleményei) mint a templom egyes részei, így domborművei, oszlopai, oltára, építőkövei. A Tanta 20 pedig kifejezetten egy épület emeléséről ír (aedificatum est). ${ }^{68}$ Jóllehet az előbbiekben említett Tanta 2-8c a Digesta hét részét közölve nem nevezi meg, hogy az egyes részek minek felelhetnek meg, mind a számszimbolika, mind a felépítmény árulkodó. ${ }^{69}$ Ugyanis a vestibulum és az arcana nagyon is kézzel foghatóan egy-egy részre utalnak. A Tanta 11-ben a vestibulum nem más, mint a bevezető $\pi \rho \tilde{\tau} \tau \alpha$ nevezetủ része a Digestának, míg az arcana, azaz a templom legbelső szentélyrésze éppen az a negyedik rész, amely a legszebb, és tegyük hozzá, a legnehezebb joganyagot rejti magában. Ahhoz tehát, hogy az elsőéves joghallgató ne a Digesta legszebb és legnehezebb jogtudósi véleményeivel küzdjön, szükséges, hogy a vestibulumban időzve képezze magát, és a jog legelemibb részét elsajátítva élvezhesse később a templom igazi pompáját. A templom roppant nagysága lenyügözi szemlélőjét - jelen esetben az elsőéves joghallgatót - és ragyogása miatt csak hunyorgó szemekkel képes az oda belépő befogadni a látványt.

${ }^{67}$ Pazdernik szerint Iustinianus hangsúlyozva Róma és a római jog kontinuitását, saját magát a múlt hagyományainak megőrzőjeként mutatja be rendeleteiben. A múlttal való kapcsolattartás legitimációt ad az uralkodónak, aki egyszersmind a joganyag és a birodalom megújítója is. Pazdernik hangsúlyozza, hogy a iustinianusi jogalkotás egyrészt saját propagandájának médiuma, másrészt fontos eszköz uralma megszilárdításához (lásd Pazdernik: i. m. [22. jegyz.] 186-187; hasonlóan Karamboula: i. m. [12. jegyz.] 4-5). A múlt joganyagának feldolgozása, nevezetesen a jogtudósok műveinek kontinuitása legitimálja az uralkodó hatalmát, törvényműve tehát eszközként szolgál birodalma összetartásában. Így például a Tanta pr:: Romanam sanctionem ab urbe condita usque ad nostri imperii tempora, quae paene in mille et quadringentos annos concurrunt..., azaz a római jog anyaga a város alapításától egészen a császár uralkodásáig, „kis költői túlzással” kb. ezernégyszáz év anyagát jelenti. Lásd ehhez Karamboula: i. m. (12. jegyz.) 4 skk.

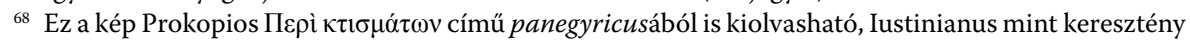
uralkodó a világ építőmestere (lásd Prok. aed. I 1, 66-67; I 10, 10). Vö. ehhez Cameron: i. m. (12. jegyz.) 87. ${ }^{69}$ Ez az értelmezés spekulatívnak is tűnhet, ugyanakkor tény, hogy a Digesta egy nagyon tudatosan komponált mű, és a számok ezen természetének az ókori gondolkodásban jóval nagyobb szerepet szántak. Az ókorban uralkodó szemlélet miatt kapott a számszimbolika komoly szerepet Iustinianus kodifikációjában is. 
Ehhez képest visszafogottabb Wallinga, aki iustitia temploma alatt a jogi műveltség és oktatás tárházát érti, amelyben az arcana a legkifinomultabb jogi tudás kincseskamráját jelképezi. Ezen metafora használata pedig szerinte nem véletlen, mivel Iustinianus ennek révén kíván egyszerre utalni tervére, azaz Róma visszahódítására, a kodifikációra és a várostervezésre. ${ }^{70}$ Honoré pedig egyszerüen az igazságosság templomáról beszél, amely a kor jogtudósairól és jogászairól mint az „igazság szolgálóiról”71 kialakult véleményt tükrözi. ${ }^{72}$

Kérdés, hogy miként értelmezhetjük ezt a leírást. Esetleg ovasható-e ekphrasisként, ez esetben merész gondolatként eszünkbe juthatnak más hasonló aranykori ekphrasisok, különösen Vergilius Aeneiséből. Viszont ehhez nagyon tágan kellene értelmeznünk az ekphrasis fogalmát. Ugyanakkor kétségtelen, hogy a templom, a múltra történő utalás, a templomra reagáló csodálkozó néző, jelen esetben az elsőéves joghallgató hármasa egy ekphrasis-szerű érzést adhat. A választás pedig nem véletlen. Ha Iustinianus várostervezésére gondolunk, ${ }^{73}$ akkor a Nika-lázadásban leégett Hagia Sophia 532-537 közti újjáépítése juthat eszünkbe.

További kérdésként merülhet fel, ${ }^{74}$ hogy vajon itt az a hangsúlyosabb, hogy ez egy építmény, és mivel abból a legtökéletesebb a templom, ezért említ templomot a szöveg, vagy itt a hangsúly azon van, hogy a Digesta egy templomhoz hasonlóan szent szöveg. Úgy vélem, hogy ez utóbbi értelmezés a helytállóbb, amelyet például az is megerősít, hogy a Digesta soraira mindig versusként ${ }^{75}$ utalnak a rendeletek, és csak kata poda idézését engedélyezte Iustinianus, ${ }^{76}$ hasonlóan a Biblia soraihoz. Iustinianus ugyanis meg volt győződve törvénykönyve „szent és sérthetetlen” voltáról. Továbbá a joghoz a templomhasonlat azért is közelebb áll, mert a jog eredendően a szakrális szférából vált külön normarendszerré, ${ }^{77}$ és ezen minőségét gyakran megőrizte jogintézményeiben is.

A „szöveg mint építmény” nem egy szokatlan kép az antik költészetben, számos előzménnyel rendelkezik. Megtaláljuk Vergiliusnál is a Georgica 3. könyvében:

et viridi in campo templum de marmore ponam

propter aquam, tardis ingens ubi flexibus errat

70 Wallinga: i. m. (26. jegyz.) 62-63.

71 Ulpianus nevezi egyenesen Iustitia papjainak a jogászokat. Lásd T. Honoré: Tribonian. London 1978. 31.

${ }^{72}$ Honoré: i. m. (71. jegyz.) 31.

73 Wallinga: i. m. (26. jegyz.) 63 szerint az egybeesés tudatosan Iustinianus „polyprogram”-ját volt hivatott jelképezni, itt pedig kimondottan a császár városépítési programjára utal.

${ }^{74}$ Ezt az értelmezést továbbárnyaló kérdést Kárpáti András vetette fel, amit ezúton is nagyon köszönök neki.

${ }^{75}$ Lásd például Tanta 1:... in centum quinquaginta paene milia versuum totum opus consummantes...; Omnem 1:... versuum autem tricies centena extendebatur ...

76 Tanta 21: ...nec qui postea fuerint audeat commentarios isdem legibus adnectere: nisi tantum si velit eas in Graecam vocem transformare sub eodem ordine eaque consequentia, sub qua voces Romanae positae sunt (hoc quod Graeci kata poda dicunt)...

77 Zlinszky J.: Állam és jog az ősi Rómában. Budapest 1996. 24-25; Földi-Hamza: i. m. (1. jegyz.) 85. 
Mincius et tenera praetexit harundine ripas.

In medio mihi Caesar erit templumque tenebit

(Verg. Georg. 3, 13-16) (8 $^{2}$

A 13. sorban szereplő templum de marmore ponam 'márványból templomot fogok emelni' - miként arra Richard Thomas ${ }^{79}$ és Mynors ${ }^{80}$ is felhívják a figyelmet - Pindaros 6. olympiai ódájából származó metaforát jelenít meg, ahol az épületmetafora egy irodalmi müre utal, a költő teljesítményét egy versenygyőztesének kijáró megbecsüléshez hasonlítva ${ }^{81}$ Mynors elveti azt a gondolatot, hogy ez egy valóságban emelt templomra - netán Caesar valódi templomára utalna ${ }^{82}$ - és jelzi, hogy egy költő képzeletbeli temploma nem olvasói szeme előtt áll Rómában, hanem egy olyan helyen, amelyet maga a költő jelenít meg olvasóinak lelki szemei előtt. Ez pedig, ha egy későbbi müre utal, egy epikus mű lehet, amely Trója felé tekint vissza, azaz az Aeneis. ${ }^{83}$

A költő művének is megvan a saját szerkezete, amelyről mint egy épület szerkezetéről nyilatkozik alkotója ${ }^{84}$ ekként láthatjuk Pindarosnál is hatodik olympiai ódájának prooimionjában:

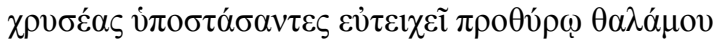

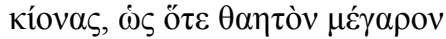

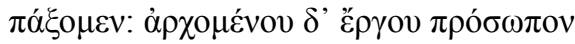

$\chi \rho \grave{\eta} \theta \varepsilon \dot{\varepsilon} \mu \varepsilon v \tau \eta \lambda \alpha v \gamma \varepsilon \dot{\varepsilon}{ }^{85}$

(Pind. Ol. VI, 1-4)

78 „Rét közepén, a nagy ár mentén, lustán tovakúszó / Minciusunknál, mely hajlós náddal szegi partját. / Caesar temploma lesz ez a hely, képmása középen.” Lakatos István fordítása.

${ }^{79}$ R. F. Thomas (ed.): Virgil's Georgics Volume 2: Books III-IV. Cambridge 1988. 41. ad loc. 13. Továbbá jelzi, hogy az Eclogákban is szerepel egy hasonló sor: levi de marmore tota / ... stabis (Ecl. 7, 31-32). Robert Coleman kommentárja szerint a VII. ecloga ezen fordulata éppen a Georgica 3, 13 passzív megfelelője (lásd R. Coleman: Vergil Eclogues. Cambridge 1977. 215-216). Hasonlóan a VII. ekloga és Georgica párhuzama kapcsán lásd W. Clausen: Virgil's Eclogues. With an Introduction and Commentary. Oxford 1995. 224.

${ }^{80}$ R. A. B. Mynors: Virgil's Georgics edited with a Commentary. Oxford 2000. 181. ad loc. 13: a metafora gyökere Vergiliusnál kettős, egyrészt Pindaros hatodik olympiai ódájának prooimionjának allúziója (Pind. Ol. VI, 1-4), másrészt Rómában hagyományosan a katonai ünnep megünneplésének egyik módja volt győzelmi templom emelése, mintegy a győzelem esetére az isteneknek felajánlott áldozati cselekvés. (Vö. ehhez például Iuppiter Stator templomának történetét Liviusnál Ab urbe cond. I, 12, 4-6).

${ }^{81}$ Mynors: i. m. (80. jegyz.) 181.

${ }^{82}$ Mynors hivatkozik Drew nézetére kommentárjában, aki szerint Vergilius jelen lehetett Julius Caesar templomának felszentelésénél Kr. e. 29 augusztusában, valamint Apollo fiának a Palatiumon emelt templomának felavatásán Kr. e. 28 októberében, és ilyen élmények hatására születhetett a Georgica ezen képe. Lásd Mynors: i. m. (80. jegyz.) 181.

${ }^{83}$ Mynors: i. m. (80. jegyz.) 181.

${ }^{84}$ C. M. Bowra: Pindar. Oxford 1964. 20-21.

85 Építsünk aranyoszlopokat, amelyek megtámasztják az épület erős falú előcsarnokát, mintha egy csodálatos palotát (emelnénk); ugyanis a mủ elejének homlokzatát messze ragyogóvá kell tenni. 
A költő művét egy ragyogó palotához, mint valamiféle kincsesházhoz, ${ }^{86}$ annak kezdetét pedig az épület messze ragyogó homlokzatához hasonlítja. Hogy pontosan milyen épületről lehet szó, és hogy annak mi lehet a funkciója, erre vonatkozóan - Adorjáni Zsolt értelmezése nyomán - maga a szöveg is nyújt információkat. A $\pi \rho o ́ \theta v \rho o v$ Pindarosnál gyakran a szó homérosi értelmében szerepel és 'egy profán épület homlokzatát' jelenti. A $\mu \varepsilon \dot{\gamma} \alpha$ pov szintén homérosi értelemben a 'királyi palotát', valamint annak termeit és csarnokait jelenti, és Pindaros is ebben az értelemben használja. ${ }^{87} \mathrm{~A} \theta \alpha \dot{\lambda} \lambda \alpha \mu \mathrm{o} \varsigma$ is 'a ház/királyi ház legbelső részét' jelentheti, itt pedig pars pro toto jelleggel jelenti magát a zárt épületet, szemben a nyitott homlokzattal ( $\pi \rho$ ó $\theta \nu \rho o v) .{ }^{88}$ Mindezek alapján egy épületkomplexumról lehet szó, valószínüleg királyi palotáról vagy arisztokrata házról, ugyanakkor Adorjáni hozzáteszi, hogy nem kell konkrét épületre gondolni, mert önmagában a fent említett kifejezések használata is az arisztokrata jólét terét alkotja meg, így bármilyen épületet megjeleníthet, profánt és szakrálisat egyaránt. ${ }^{89}$ Ugyanakkor Pindaros nem egy fizikai valóságban létező épületre utal, hiszen aranyoszlopai is éppen roppant nagyságát és égi voltát hangsúlyozzák inkább. ${ }^{90}$

Pindaros a $\chi \rho v \sigma \varepsilon ́ \alpha \varsigma$... $\pi \alpha ́ \xi o \mu \varepsilon v$ részben felvezeti a képet, amelyen belül egy hasonlító partikulát alkalmaz ( $\dot{\zeta}$ ő $\varepsilon \varepsilon \theta \alpha \eta \tau o ̀ v ~ \mu \varepsilon ́ \gamma \alpha \rho o v)$. A második részt sokkal absztraktabb módon szerkeszti, és az előző képet felhasználva egy általános szabályt fogalmaz meg $(\chi \rho \grave{)}){ }^{91}$ A hasonlító partikulával kezdődő rész - amely Vergilius megoldásaival ellentétben ${ }^{92}$ - ismerös szerkesztés a Deo auctoréból is (quasi proprium et sanctissimum templum iustitiae consecrare), ahol jóval zártabb a metafora, és kifejezetten szakrális épületre utal.

Az autoreflexív mủ a vizualitást helyezi a középpontba, ${ }^{93}$ és a látványt a közönség nézőpontjából írja le, ekként kívülről tekint az épületre, azaz a versre. ${ }^{94}$ Ugyanez figyelhető meg a Tanta esetében is, a Digesta templomának roppant nagyságára az olvasó lenyügözöttségével utal. Olyan vakító ragyogást tulajdonít a münek, hogy az oda belépő avatatlan szemek csak hunyorogva képesek a látványt befogadni (et formam legum pulcherrimam non coniventibus oculis accipere).

${ }^{86}$ Bowra: i. m. (84. jegyz.) 21.

${ }^{87}$ Adorjáni Zs.: Pindars Sechste Olympische Siegesode. Text, Einleitung und Kommentar. Leiden Boston 2014. 117.

${ }^{88}$ Adorjáni: i. m. (87. jegyz.) 117.

${ }^{89}$ Adorjáni: i. m. (87. jegyz.) 117-118.

${ }^{90}$ Bowra: i. m. (84. jegyz.) 21.

${ }^{91}$ Adorjáni: i. m. (87. jegyz.) 118.

${ }_{92}$ Richard F. Thomas jelzi, hogy jóllehet Pindaros mủve lehetett a minta Vergilius számára a Georgica 3, 13-ban megjelenített kép esetében, de Vergilius metaforája az egész háromsoros részen végigvonul, míg

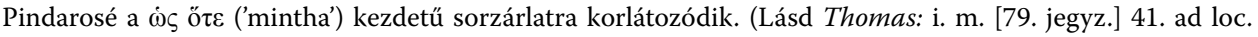

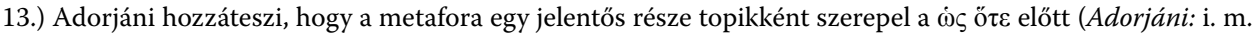
[87. jegyz.] 118.).

${ }_{93}^{93}$ Lásd Adorjáni: i. m. (87. jegyz.) 115.

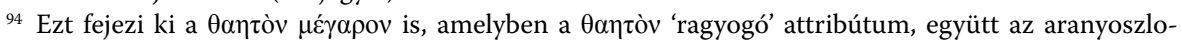
pokkal egyrészt hangsúlyozza a költemény előkelő voltát, másrészt a látványt kívülről jelenítik meg (lásd Adorjáni: i. m. [87. jegyz.] 121.) 


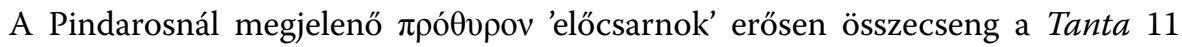
vestibulumával, figyelemmel arra, hogy az elsőéves joghallgatót is lenyűgözi a Digesta templomának megjelenése már csak vestibulumával is. Pindarosnál továbbá a $\pi \rho o ́ \sigma \omega \pi o v$ 'homlokzat' ${ }^{\prime 2}$ is látványelemként szerepel, és a mủ kezdetének mint egy épületnek a hom-

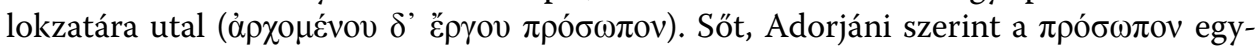
szerre utal a vers épületének belsejére is. ${ }^{96} \mathrm{~A}$ Tanta ennél sokkal nyilvánvalóbban jeleníti meg a törvénykönyv templomának vestibulumában állókat, akik az arcanába készülnek belépni (et qui in primis legum vestibulis stantes intrare ad arcana eorum properant).

A Deo auctore és Tanta esetében is mind a látvány szemléltetése, mind a metafora mủködése hasonló Pindaroséhoz. És talán nem véletlen ez sem. Prokopios Пвpì

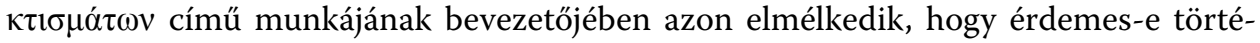
netírásra vállalkozni, majd miután rátér munkája tárgyára, nevezetesen az épületekre,

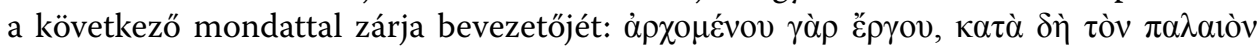

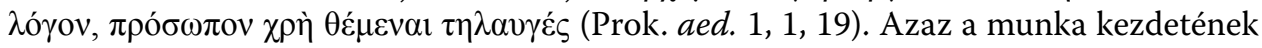
homlokzatát a régi tanács szerint is messze ragyogóvá kell tenni. Az antik költészetben egy közismert és méltán ünnepelt képről van szó, amely a kodifikáció bevezető rendeleteinek pompázatos sorait szerkesztők figyelmét sem kerülte el, és a Digestát is méltónak találta erre a metaforára.

A képhez végül még egy érdekes adalék, hogy Sir William Blackstone - XVIII. századi jogtudós - szerint, a jog csodás építménye, amelyhez saját munkája a térkép a jogtanulók kezében, leginkább egy gótikus kastélyhoz hasonlítható: „We inherit an old Gothic castle, erected in the days of chivalry but fitted up for a modern inhabitant. The moated ramparts, the embattled towers, and the trophied halls, are magnificent and venerable, but useless. The inferior apartments now converted into rooms of convenien$c e$, are cheerful and commodious, though their approaches are winding and difficult.9.7 Blackstone tehát a jog építményéről mint régi örökségről beszél. Az angol jogról lévén szó nem meglepő, hogy a lovagkor napjaiban keletkezett, és ennek megfelelően az épület is éppen egy gótikus kastély. Fontos, hogy hozzáteszi az angol jogra jellemző sajátosságot, miszerint modern lakója számára is megfelelő építményről van szó, amellyel utal a precedens rendszer alapvető tulajdonságaira. Ugyanakkor a múlt intézményei, amelyeket a sáncárkokkal körülvett falak, az ostromlott tornyok és a hadizsákmánytól csillogó termek képviselnek, jóllehet lenyűgözőek és tiszteletreméltóak, de hasznavehetetlenek. A jognak is szüksége van ugyanis megújulásra, így a metaforában is jelzi a szerző, hogy az alsóbb szintek most kényelmes szobákká alakultak át, amelyek vidámak és tágasak, megközelítésük mégis kanyargós és nehéz. A metafora a modern kor követelményeihez

${ }^{95}$ Adorjáni felhívja a figyelmet rá, hogy egyaránt van aktív ('tekintet') és passzív ('arc') értelme, és itt

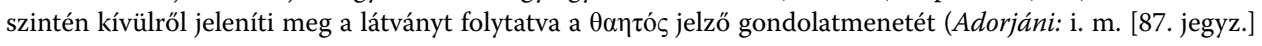
123.)

${ }_{96}$ Adorjáni: i. m. (87. jegyz.) 123.

97 Sir William Blackstone: Commentaries on the Laws of England (facsimile). Oxford 1765-1769. Book III. 268. és W. Prest (ed): The Oxford Edition of Blackstone's Commentaries on the Laws of England. Book III of Private Wrongs. 178. 
igazodott joganyagra utal ezzel a fordulattal. A jognak egy épülethez való hasonlítása a mai napig a jogászok közkedvelt metaforája, ha kellően hangzatosan szeretnének fogalmazni, bár manapság inkább útvesztőkhöz lehet a jog építményét hasonlítani.

A jog elemei éppúgy építőkövei az egész jogrendszernek, mint ahogyan egy épület esetében a téglák. Ezek az építőkövek szükségesek, és ha meggondolatlanul távolítunk el belőlük egyet is, inogni fog az épület. Ahogyan egy épület, úgy a jog is folyamatos renoválásra szorul a társadalmi viszonyoknak megfelelően, a renoválás azonban sosem jelenti az építmény alapjainak lebontását, hiszen ahogy egy templom oltárkövét sem cserélik ki, úgy a jog felépítményének alapvető elemeit sem szabad kicserélni, hanem tisztelettel kell rájuk tekinteni.

A Tanta 20 az Index Auctorum összeállításáról rendelkező szakasza utal kifejezetten a templom építőköveire: ut manifestissimum sit, ex quibus legis latoribus quibusque libris eorum et quot milibus hoc iustitiae Romanae templum aedificatum est. Azaz a jogtudósok véleményeit, közelebbről a római jogtudomány műalkotásait tekinti a templom építőköveinek. Ez kettőssé teszi a metaforát, hiszen egyrészről a pindarosi minta nyomán a Digesta mint az igazságosság temploma értelmezhető, azaz a törvénykönyv mint épület, valamint a joganyag „szentségére” való tekintettel egy szakrális épület tárul az olvasó szeme elé. Ugyanakkor maga a jog is mint épület, a jogtudomány elemei mint a jog építőkövei jelennek meg ebben a képben. A Digesta bevezető rendeleteinek szerzője tehát a két képet összevonva jeleníti meg a Digestát mint a jog és igazságosság templomát.

Sem ennek a helynek, sem a Tanta előbb említett szöveghelyeinek nincs párhuzamos megfelelője a $\Delta \varepsilon ́ \delta \omega \kappa \varepsilon v b e n .{ }^{98}$ Wallinga kiemeli, hogy a Tanta ilyen tekintetben sokkal inkább szolgálhatta a propagandát, amely azt hirdette, hogy a császár egy augustusi aranykor visszaállításán fáradozik. ${ }^{99}$ Ugyanakkor a keleti birodalomfélben a latin nyelv a göröghöz képest jóval kevésbé volt alkalmas ilyen propaganda terjesztésére, így szükség volt a görög nyelvü propagandára is. Ez pedig verses formában jelentkezett. A Digestát megőrző Codex Florentinusban az Index titulorum végén szerepel egy hexameteres költemény ismeretlen költőtől, amelyet a kritikai editiók (Mommsen; Krueger) is hoznak, valamint az Anthologia Graeca Appendix kötetében is szerepel: ${ }^{100}$

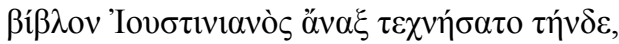

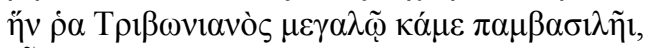

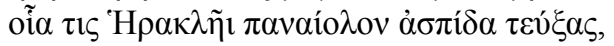

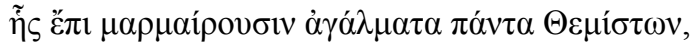

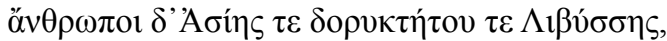
Eủ

98 Wallinga ezt Ebrard nézetét osztva a sietséggel magyarázza. Részletesen lásd Wallinga: i. m. (26. jegyz.) 65.

99 Wallinga: i. m. (26. jegyz.) 63.

100 Lásd Ed. Cougny (ed.): Epigrammatum Anthologia Palatina cum Planudeis et appendice nova. Vol. 3. Paris 1871. 191. 
„Eme könyvet Iustinianus császár találta ki, és azután Tribonianus készítette azt el a leghatalmasabb uralkodónak úgy, mint amikor valaki Héraklésnek egy ragyogó pajzsot faragott, amelyen a Törvények valamennyi képmása csillog, Ázsia népei pedig, és a fegyverekkel (vissza)szerzett Afrikáé és Európáé engedelmeskednek az egész világ irányítójának."

A Iustinianus dicsőségét hirdető költemény a kodifikáció szerzőségének kérdését is felveti. Jóllehet a császár rendelte el a kodifikációt, és a törvények az ő neve alatt kerültek kihirdetésre, mégsem ő a kivitelezője e hatalmas munkának, hanem az a számos kiváló jogtudósból álló bizottság, akik a császár neve mögött - a posztklasszikus és általában császárkori bevett megoldással szemben ${ }^{101}$ - éppen a bevezető rendelkezéseknek köszönhetően nem teljesen névtelenül szerepelnek, hanem sokszor, terjengős címeikkel együtt említik őket. ${ }^{102}$ A hexameteres görög szöveg kifejezett feladatmegosztást mutat, amelyben a $\tau \varepsilon \chi v \alpha ́ o \mu \alpha \imath$ ige $\mathrm{S} / 3$. aoristosa szerepel, amely egyrészt azt jelenti, hogy 'kigondol, kieszel', másrészt, hogy 'kiválóan, ügyesen véghezvisz.' ${ }^{103}$ Azaz a császár nemcsak kigondolta, hanem eszközöket biztosítva, a megfelelő embereket a feladat elvégzésére kijelölve véghez is vitte kodifikációját. A második sorban Tribonianus kapcsán a költő a кó $\mu v \omega$ igét használja, amely 'fáradozik, megépít, dolgozik' jelentésekkel bír. ${ }^{104}$ Tehát a kodifikáció „értelmi szerzője” tagadhatatlanul Iustinianus volt, miközben kivitelezője elsősorban Tribonianus.

A költemény harmadik sorában egy érdekes hasonlat szerepel, amely a Digesta összeállítását irányító Tribonianust olyasvalakihez hasonlítja, aki Héraklés ragyogó pajzsát elkészítette, aki pedig köztudomásúlag nem más, mint Héphaistos. A költemény

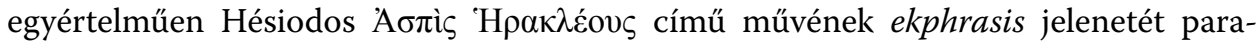

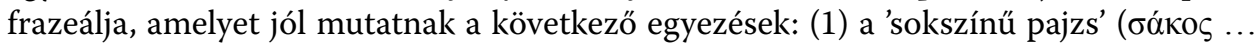

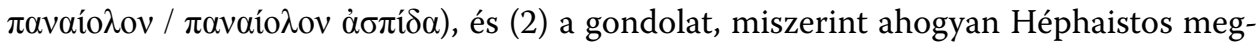
alkotta Héraklés pajzsát Zeus akarata szerint, úgy alkotta meg Tribonianus a Digesta törvényművét Iustinianus rendeletei alapján a császár ihletettségétől vezérelve.

A pajzs metaforában egyszerre jelenik meg a iustinianusi program mindkét célkitűzése: egyrészt utal a háborúkra, amelyeket a császár vívott, másrészt - ahogy a negyedik sorból megtudjuk - olyan pajzsról van szó, amelyen a Törvények valamennyi

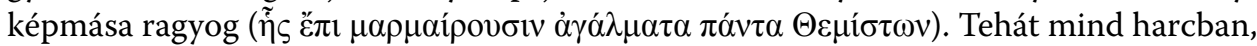

101 Pólay kiemeli, hogy a császárkorban folyamatosan kiépülő bürokrácia jelentős hatással volt az addig saját nevük alatt szakvéleményt osztogató jogtudósokra, mivel fokozatosan betagozódtak az államgépezetbe, amennyiben véleményeiket a hivatalnoki apparátus tagjaként, névtelenül, a császár nevében alkották. Lásd részletesen a kérdéshez Pólay: i. m. (18. jegyz.) 167.

102 Vö. a Digesta összeállító bizottságához Tanta 1, 9 és 11; Imperatoriam 3; Omnem 2, 6; Haec quae necessario 1; Summa 2; Cordi nobis 2. A hivatalos címzések a jogtudós megnevezéséhez hozzátartoztak, a téma alapos ismertetéséhez lásd Kelemen M.: A Birodalom kormányzása. Budapest 2006. passim és Kelemen M.: A bizánci igazgatástörténet vázlata. In: Rácz L. (szerk.): Kormányzás és kodifikáció: tanulmányok az újkori Európa fejlődéséről. Budapest 2006. 11-51.

${ }_{103}$ LSJ s. v. $\tau \varepsilon \chi v \alpha ́ o \mu \alpha 1$.

${ }^{104}$ LSJ s. v. $\kappa \alpha ́ \mu v \omega$. 
mind béke idején hasznát veszi az uralkodó birodalmának fenntartásában és védelmezésében.

Az ơ $\gamma \alpha \lambda \mu \alpha$ ugyanakkor nem egyszerűen csak általános képeket, képmásokat jelent, hanem vallási többletjelentéssel is bír. Az ő $\gamma \alpha \lambda \mu \alpha$ ugyanis az isteneknek felajánlott áldozati ajándékot, továbbá az istenek tiszteletére állított szobrot is jelenti. ${ }^{105} \mathrm{~A}$ szobrokat

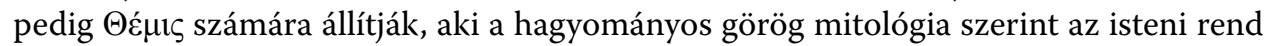

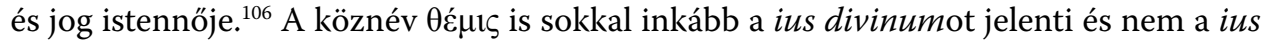

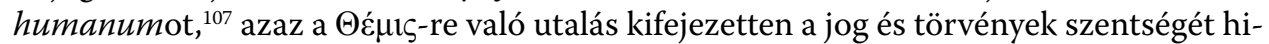

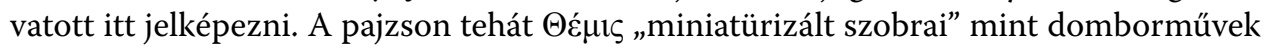
sorakoznak, és maga az egész törvénykönyv egy, az isteni szentség felé történő felajánlásként ${ }^{108}$ értelmezhető ebben az összefüggésben. Mivel Iustinianus koráról beszélünk, ez a szentség egyértelműen keresztény olvasatban értelmezendő. Ezen ponton viszont a hésiodosi mintától eltér, ugyanis Héraklés pajzsán nem Themis szobrai és domborművei állnak, hanem egészen más jelenetek, így a félelem, a harc és vadság jelenetei stb. szerepelnek, míg Iustinianus „pajzsa” a törvényeket és a rend képmásait jeleníti meg. Az ötödik és hatodik sorokban pedig ismételten visszatér a birodalom növelésének gondolata, amelyben szerepet kap a visszahódított Afrika és érdekes utalásként Európa. Európa alatt nem más értendő, mint az egykori imperium Romanum itáliai, hispániai területei, valamint azon további területek, amelyek valaha a részét képezték a birodalomnak. Az imperium Romanum iránti nosztalgia állandóan érezhető Iustinianus rendeleteiben. A magát a rómaiság restaurátorának hirdető császár ${ }^{109}$ azonban ebben a költeményben mintha megelőlegezné a későbbi sikereket, hiszen a Digestát 533-ban léptette csak hatályba Iustinianus, amikor „Európa” visszahódítása még csak a következő hódításként lebegett optimista szeme előtt. Ehhez képest a császár alakja az utolsó

105 LSJ s. v. ơ $\gamma \alpha \lambda \mu \alpha 2$. és 3. jelentése.

106 A római istenek közül Diké alakjának Iustitia felel meg (igazságosság), aki Themis (az isteni törvény)

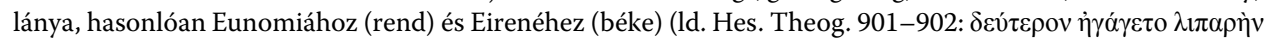

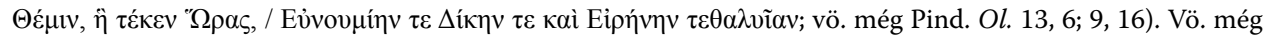
http://www.theoi.com/Titan/TitanisThemis.html

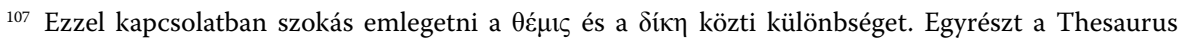

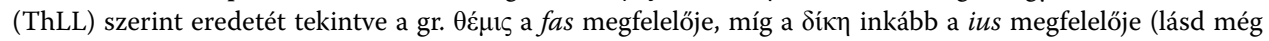

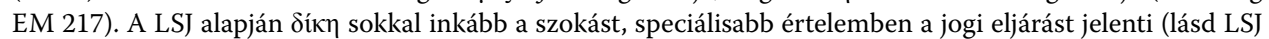

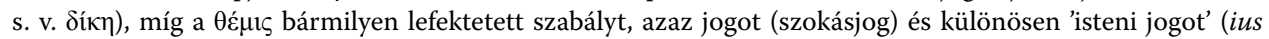

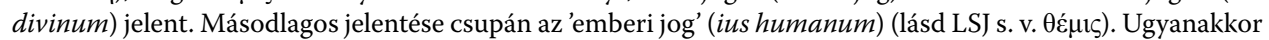

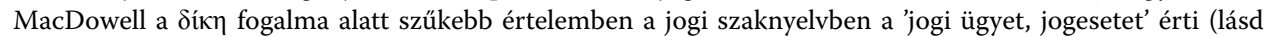
D. M. MacDowell: The Law in Classical Athen. Ithaca - New York 1986. 44-45).

108 Maas hangsúlyozza, hogy a keresztény uralkodó a kodifikációra mint Istennek tetsző tettre tekintett, és ennek a felfogásnak egy klasszikusan római oka volt, ti. az egész birodalom jóléte az isteni szférával való jó kapcsolattartástól függött (lásd Maas: i. m. [1. jegyz.] 14 és 22). A klasszikus római engesztelő jellegű valláshoz lásd még részletesen Köves-Zulauf: i. m. (23. jegyz.) 110.

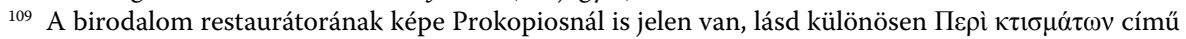

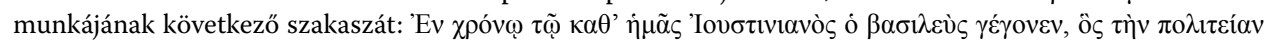

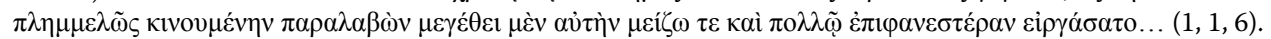
Vö. még Cameron: i. m. (12. jegyz.) 86-87. 


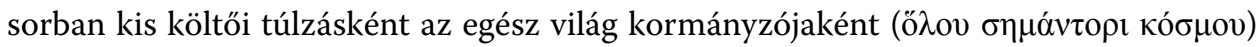
jelenik meg.

Ez a gondolat a latin nyelvű rendeletek közül az Imperatoriam kezdetű constitutióban is megjelenik:

Quorum utramque viam cum summis vigiliis et summa providentia adnuente Deo perfecimus, et bellicos quidem sudores nostros barbaricae gentes sub iuga nostra deductae cognoscunt et tam Africa quam aliae innumerosae provinciae post tanta temporum spatia nostris victoriis a caelesti numine praestitis iterum dicioni Romanae nostroque additae imperio protestantur. omnes vero populi legibus iam a nobis vel promulgatis vel compositis reguntur. (Imperatoriam 1)
Miután ezeknek mindkét célját Isten áldásával elértük a legfőbb éberséggel és a legnagyobb gondossággal, már a barbár népek is, akiket igánk alá hajtottunk, hadi verítékünket ismerik, és úgy Africa, mint számtalan más provincia ennyi idő elteltével ismét elismerni kényszerül az égi akarat által megadott győzelmeink miatt a római állam fennhatóságát és a mi ahhoz kapcsolódó uralmunkat, most már valóban minden népet az általunk összeállított és kihirdetett törvények szerint kormányzunk.

A latin szöveg jól láthatóan jelzi, hogy erre a feladatra Isten kedvezésével került sor. A görög szöveg első pillantásra sokkal inkább egy mitológiai jelenetet idéz fel az olvasóban, valamint a hódító és törvényekkel uralkodó császár képét. ${ }^{110}$ Viszont a görög nyelvű vers, jóllehet ellentétben a templommetaforával nem utal egyértelműen a kodifikáció keresztény voltára, ${ }^{111}$ a pajzs szimbolikája mégis árulkodó. A pajzs egy olyan eszköz, amely az uralkodókat és Istent szimbolizálja a Bibliában mint népüket védelmezőket. ${ }^{112}$ A keresztény kodifikáció pajzsa, azaz a Digesta, tehát éppen ezt a funkcióját tölti be, hogy a már visszahódított területek népeit megvédje az uralkodó, így gondoskodva az „egykori imperium Romanum” védelméről. Ez az ábrázolásmód is jól mutatja, hogy a klasszikus és új elemek ötvözete jellemzi a császári propagandát. A régi kor iránti nosztalgia és az új kor iránti tisztelet vegyesen van jelen Iustinianus kodifikációjának bevezető rendeleteiben, jól példázva, hogy Iustinianus egy személyben testesítette meg a klasszikus kori római tradíció restaurátorát és a keresztény Bizánc reformátorát.

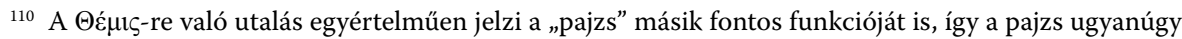
képes megjeleníteni mindkét birodalmi célt.

111 Ugyanakkor a $\Delta \varepsilon \delta \delta \kappa \varepsilon v$ számos helyen utal a keresztény kodifikáció gondolatára, így $\Delta \varepsilon \dot{\delta} \omega \kappa \varepsilon v p r$ :

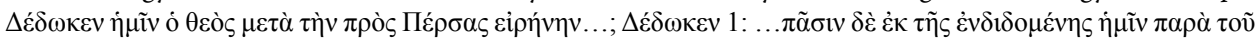

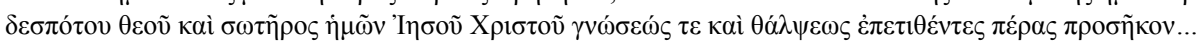

112 Lásd például Deut. 33, 29: Beatus tu Israhel, quis similis tui popule, qui salvaris in Domino scutum auxilii tui, et gladius gloriae tuae: negabunt te inimici tui, et tu eorum colla calcabis; Samuel 2, 1, 21: ....montes Gelboe nec ros nec pluviae veniant super vos neque sint agri primitiarum quia ibi abiectus est clypeus fortium clypeus Saul quasi non esset unctus oleo... 
Összefoglalva a fentieket, Iustinianus császár uralkodása idején a Római Birodalom, a központi propaganda szóhasználatával fogalmazva, egy új aranykorba lépett, és ez a gondolat mind a császár nyelvpolitikai intézkedéseiben, mind hódításaiban, mind kodifikációjában tetten érhető. A Shepard-féle 'grand design' megvalósítását számos intézkedés szolgálta, de a propagandában kiemelkedő szerep jutott a kodifikáció bevezető rendeleteinek.

A rendeletekben számos stilisztikai alakzat és szókép figyelhető meg, amelyek szerepe nem más, mint hogy a császár dicsőségét magas szépirodalmi szinten is magasztalják, és a birodalom minden alattvalójához a propaganda részeként eljuttassák. A két birodalmi cél, nevezetesen a hódítás és a kodifikáció kiemelése mellett a rendeletek hangsúlyozzák, hogy ez a kodifikáció Isten segítségével jött létre, így egy keresztény Római Birodalomként született újjá az egykori imperium Romanum. A Digesta, amely központi helyet foglal el az egész kodifikáció folyamatában, nem más, mint az igazságosság legszentebb temploma, amelybe a belépő elsőéves jogtanuló lenyűgözve csodálhatja a klasszikus kor jogtudósainak remekműveit. A Digesta mint templom kettős értelemben is metafora, hiszen maga a törvénykönyv is mint templom jelenik meg, de egyúttal azt is szimbolizálja, hogy a jognak is megvannak a maga építőkövei. A Digesta mint pajzs az Index Titulorum végén szereplő hexameteres görög nyelvű költeményben a hódító és törvényekkel uralkodó császár legfontosabb eszközeként jelenik meg, továbbá ez a metafora is része keresztény kodifikációra utaló képeknek, a népét védő uralkodó képét is felidézve az olvasóban.

Mindezek alapján elmondható, hogy az a 'grand design', amelyet Iustinianus megálmodott, a hatásos és magas színvonalú propagandának köszönhetően második aranykorként úgyszolván fizikailag is érzékelhetően ragyogta be a birodalmat a középkor felé tartó Bizánc kapujában, egyszersmind elmondható, hogy a császár nagyratörő vágyát kodifikációja történelmi távlatban is messzemenően megvalósította, hiszen a iustinianusi törvénykönyvek mai napig a jog alapját jelentik. 


\title{
SUMMARY
}

In the sixth century, the legislation of Emperor Justinian was probably made with the utmost care and concern. The Christian ruler regarded himself as the restorer of the classical Roman tradition and also a great reformer. This was mainly pointed out in his decrees. In the introductory decrees of his codification emphasized that there is a dual imperial objective, namely the re-emergence of the imperium Romanum and the codification of classical law, both goals viewed as service to God. In the centre of the Christian codification of Justinian, the Digest stands for a particular reason the emperor gave it, raising up the own and most holy temple to justice for his subjects. The introductory decrees use metaphors in order to convince the reader of his sacred goals and to ensure his subjects that his legislation will be the protector of the State and the development of the legal institutions under the cloak of the restauration of ancient Roman tradition.

Keywords: Justinian, codification, Digest, Deo auctore, Tanta, $\Delta \varepsilon \dot{\delta} \omega \kappa \varepsilon v$

\author{
Nemes Szilvia \\ ELTE ÁJK Római Jogi és Összehasonlító Jogtörténeti Tanszék \\ ELTE Állam- és Jogtudományi Doktori Iskola \\ Állam- és Jogtudományi Doktori Program \\ 1053 Budapest, Egyetem tér 1-3. \\ nszilvie@gmail.com
}

